\title{
Effectiveness of Use of Electronic Module in Sociology Subjects of Social Change for Equality Education Package C
}

\author{
Mutia Hariyani $^{\text {1*, Dwi Kusumawardani }}{ }^{2}$, Moch Sukardjo ${ }^{3}$ \\ ${ }^{3}$ Postgraduate Educational Technology, State University of Jakarta \\ e-mail: mutiaa.hariyani@gmail.com
}

\section{A R T I CLE IN F O}

\section{Article history:}

Received June 10, 2021

Revised June 11, 2021

Accepted July 26, 2021

Available online August 25, 2021

\section{Kata Kunci:}

E-modul, Sosiologi, Pendidikan

Kesetaraan $C$

\section{Keywords:}

E-module, Sociology, Equality

Education Package C

DOI:

http://dx.doi.org/10.23887/jet.v 5i3.37719

\begin{abstract}
A B S T R A K
Proses pembelajaran masih bersifat konvensional baik dalam penggunaan metode maupun media pembelajaran sehingga mempengaruhi hasil belajar siswa. Dengan penggunaan modul elektronik, materi abstrak dapat dikonkretkan dan membuat siswa tertarik dan termotivasi dalam belajar serta dapat meningkatkan hasil belajar. Tujuan penelitian ini adalah untuk menguji keefektifan modul elektronik terhadap hasil belajar kognitif pada materi perubahan sosial pada program Pendidikan paket C. Pendekatan penelitian yang digunakan adalah pendekatan kuantitatif. Jenis penelitian yang digunakan adalah Pra Eksperimental. Desain yang digunakan dalam penelitian ini adalah One Group Pretest-Posttest. Subjek penelitian adalah siswa kelas XII program paket C yang berjumlah 38 siswa dengan rincian 17 lakilaki dan 21 perempuan. Metode pengumpulan data dengan observasi, wawancara, dan tes. Instrumen yang digunakan berupa tes objektif dengan jumlah item sebanyak 10 butir. Analisis peningkatan hasil belajar dianalisis dengan menggunakan rumus $N$-Gain. Hasil penelitian yaitu berdasarkan analisis N-gain, hasil belajar siswa menunjukkan nilai 0,60 dalam kategori sedang dan nilai efektivitas $N$-gain dalam persen adalah 60 dengan kategori cukup efektif. Sehingga pembelajaran dengan menggunakan modul elektronik dapat meningkatkan hasil belajar siswa.
\end{abstract}

\section{A B S T R A C T}

learning process is still conventional in the use of learning methods and media to affect student learning outcomes. With the use of electronic modules, abstract material can be concretized, making students interested and motivated in learning, and improving learning outcomes. The purpose of this study was to test the effectiveness of the electronic module on cognitive learning outcomes on social change material in the Package C Education program. The research approach used was quantitative. The type of research used is Pre-experimental. The design used in this research is One Group Pretest-Posttest. The research subjects were students of class XII package C program, totalling 38 students with details of 17 males and 21 females - data collection methods by observation, interviews, and tests. The instrument used is an objective test with a total of 10 items. The analysis of improving learning outcomes was analyzed using the N-Gain formula. The study results are based on $\mathrm{N}$-gain analysis, and student learning outcomes show a value of 0.60 in the medium category, and the value of the effectiveness of $\mathrm{N}$-gain in per cent is 60 with a moderately effective category. So that learning by using electronic modules can improve student learning outcomes.

This is an open access article under the CC BY-SA license.

Copyright (C) 2021 by Author. Published by Universitas Pendidikan Ganesha.

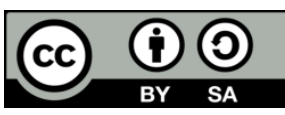

\section{INTRODUCTION}

Learning is a process of interaction between students and learning resources. Good learning is learning that is able to provide opportunities for students to explore and develop their own knowledge (Andersen \& Watkins, 2018; Diacopoulos \& Crompton, 2020; Toma \& Greca, 2018). Learning like this will make learning more meaningful. Meaningful learning is learning that provides experience and is able to develop emotional intelligence which can later be used in social life (Angela, 2014; Clay et al., 2021; Kostiainen et al., 2018). This learning principle is trying to be developed in equality education. Equality education is non-formal education that provides opportunities for children who have dropped out of school to pursue their education again. One of the equivalence education is the Study Group Package C equivalent to SMA/MA. The implementation of the Package C Program is expected to provide knowledge, skills, and mental attitudes of learning citizens (Akita \& Mori, 2021; Kaniati \& Kusmayadi, 2013). Equality students are people who have rational critical thinking, meaning that what they do is oriented to their own benefit at this time, without thinking about how important education is in life (Sutisna, 2016). In the Equality Education package C program, learning is not just to achieve 
graduation numbers, but must be able to create independence and learning creativity and usefulness in life. To make this happen, learning must be in accordance with strategies, techniques and learning methods (AragonésGonzález et al., 2020; Kisworo, 2017).

However, at this time the learning process carried out is still conventional both in the use of learning methods and media (Diah \& Riyanto, 2016; Manurung \& Panggabean, 2020; Sunismi, 2015). As in sociology learning in the package $\mathrm{C}$ equivalence program, students only get material from the teacher through lectures with the help of teaching materials such as printed modules whose content is not up to date. Students are only limited to memorizing the material without understanding what the material is being studied (Elder et al., 2019; Setiyani et al., 2020). The weakness of this printed module itself is that it is less practical to carry because it is relatively large and heavy, the script can only be arranged in a linear fashion, it cannot be completed with video in its presentation, it is only in picture form (Asrial et al., 2020; Fadli et al., 2020). This problem does not only occur in informal schools such as the package $\mathrm{C}$ equality program, the problem of limited learning modules is also experienced by formal schools. These problems, for example the model or method used by teachers in teaching are still monotonous and teacher-centered so that interaction between teachers and students is still lacking. In addition, the learning and learning process is less interesting because the use of learning media is still lacking (Raharjo et al., 2017). Of course this if left unchecked will greatly affect the quality of learning the final outcome of education.

One solution that can be used is the use of e-modules. E-module is a module in an electronic format that is run by a computer (Gerhardt-Szép et al., 2017; Resita \& Ertikanto, 2018; Wijayanti et al., 2016). The use of computer-based learning media is considered to be more optimally used in supporting education today because with learning media students can learn and analyze teaching materials themselves whenever and wherever they are without having to wait for the presence of educators to explain the teaching materials (Daniel \& Kamioka, 2017; Daniels \& Gierl, 2017; Divayana et al., 2016). Also, the availability of modules in learning activities can help and facilitate students in obtaining information related to the basic competencies taught by educators (Astalini et al., 2019; Aufa et al., 2021; Hamzah \& Mentari, 2017). E-Modules can help students to learn independently and can measure their own level of understanding (Fisnani et al., 2020; Laili et al., 2019). Emodules as a solution in the learning process because e-modules can increase student motivation and make the learning atmosphere more interesting, as well as teaching materials that can be used independently (Hamzah \& Mentari, 2017; Noroozi \& Mulder, 2017). The electronic module has an important role because it can help the learning process of students. With the electronic module, abstract material can be concreted and make an uninteresting learning atmosphere interesting. In addition, electronic modules can also be used to support independent learning in students. As well as, say that e-modules are effective for strengthening student character and are also effective in improving learning outcomes (Asmi et al., 2018; Yulando et al., 2019). With the use of this electronic module, it is hoped that students can learn easily and independently in order to understand the material at their own learning speed. The advantages of e-modules are the reason for conducting research related to e-modules.

One of the important components in the learning process is learning media (Abror et al., 2020; Budiaman et al., 2021; Hartini et al., 2017). Learning will be more interesting if the learning media is really prepared to meet the needs and abilities of students so that students can actively participate in the teaching and learning process (Gunawan et al., 2017; Prasasti et al., 2019). One of the learning media used to help students understand the material more easily is the learning module. The learning module will have a positive influence on the ability of students to understand the material and an increase in learning activities (Bock et al., 2018; Logan et al., 2021; Rasmussen et al., 2020). Modules can help students find concepts in their own activities or study in groups that will make learning more meaningful (Faidah et al., 2019; Sofyan et al., 2019). It can be said that the existence of a children's learning module will greatly assist the learning process. To achieve this goal, of course, the modules developed and used must be in accordance with the material, curriculum, user characteristics, design and description (Andrinata et al., 2016).

Several previous research findings state that the application of E-modules can provide comfort to someone who has an effect on increasing understanding of a theory (Elder et al., 2019; Winatha et al., 2018). Teaching materials by utilizing electronic modules can have a positive impact on student learning outcomes because students will more easily access and absorb learning materials (Astalini et al., 2019; Simamora et al., 2017). E-modules are also effectively used in problem-based learning processes (Mutmainnah et al., 2021; Nisa et al., 2015).The advantages of the module are that students have the opportunity to train themselves to learn independently, learn to be more interesting because it can be learned outside the classroom and outside learning hours, the opportunity to express ways of learning according to their abilities and interests, the opportunity to test their own abilities by doing the exercises presented in the module (Asmi et al., 2018; Neppala et al., 2018). So, the existence of e-module will have a very positive impact on learning outcomes, independence of elementary, junior high, high school and college students.

The relevance of this research lies in the use of digital modules. The development of e-modules has a difference from the existing e-modules, namely that the module was developed for sociology subjects for the 
package $\mathrm{C}$ equality program in PKBM. Equality students are people who have rational critical thinking, meaning that what they do is oriented to their own advantage at this time, without thinking about how important education is in life (Sutisna, 2016). In the Package C equivalence education program, learning is not just to achieve graduation numbers, but must be able to create independence and learning creativity and usefulness in life. Therefore, the media developed is in accordance with the learning objectives and the material provided. The results of media development show that the media produced is feasible to use with a very decent category with a score of $92.6 \%$. After it is known that the developed electronic module media is feasible to use, the next step is to analyze the effectiveness of the developed e-module. So that this study aims to analyze the effectiveness of the use of electronic modules on the learning outcomes of sociology subjects on social change materials in the Package $\mathrm{C}$ education program.

\section{METHOD}

This study is a research with a quantitative approach. Quantitative research is an approach to examine the relationship between variables (Creswell, 2014). This variable, in turn, can be measured using instruments, so that the total data can be analyzed using statistical procedures. The type of research used is Pre-Experimental. Pre-experimental design is used to reveal cause-and-effect relationships by involving only one group of subjects, so there is no strict control over the variables. The design used in this study is the One Group Pretest-Posttest. Research with this design has a research flow, namely before being given treatment, the class is given an initial test (pretest) to find out the learning outcomes of students. After being given a pretest, the class was then given treatment, namely by being given an electronic module that was used online. Then after that the class was given a final test (posttest) to find out whether or not there was an increase in student learning outcomes after the use of the electronic module.

This research was conducted at the Community Learning Activity Center (PKBM) Negeri 16 Rawasari. The targets of this research are students of the Package C Equivalence Program. The number of samples for this research is the class XII students of the Package C program, totaling 38 students with 17 males and 21 females. Package $\mathrm{C}$ program students are different from the characteristics of high school students in general. Package $\mathrm{C}$ program students have various age criteria ranging from the age of 16 years to 36 years and most of them are already in the adult category. At that age, students should be able to do independent learning. Therefore, the development of the students of this package $\mathrm{c}$ program is in the development of adults. The learning abilities of these package $\mathrm{C}$ students are different, some are quick to catch the subject matter being taught, some are taking a long time to catch it. The educational background of students is also different, some are junior high school graduates, some have not graduated from high school before, some need a high school graduation certificate or high school diploma, some drop out of school but want to continue school, some are of a productive age who want to improve their knowledge and life skills. Data collection methods used are interviews, observations, questionnaires and tests.

Table 1. Grid of Test Instruments

\begin{tabular}{|c|c|c|c|c|}
\hline KD & Indicator & $\begin{array}{l}\text { Cogniti } \\
\text { ve } \\
\text { Level }\end{array}$ & $\begin{array}{l}\text { Questio } \\
\text { n } \\
\text { Number }\end{array}$ & $\begin{array}{l}\text { Questi } \\
\text { on } \\
\text { Form } \\
\end{array}$ \\
\hline \multirow{10}{*}{$\begin{array}{l}\text { Understanding social } \\
\text { change, including the forms } \\
\text { of social change, the factors } \\
\text { causing social change, and } \\
\text { the consequences of social } \\
\text { change both negatively to } \\
\text { the occurrence of social } \\
\text { inequality and positively } \\
\text { encourage the progress of } \\
\text { society. }\end{array}$} & $\begin{array}{l}\text { Describing the meaning of social change } \\
\text { according to Selo Soemardjan }\end{array}$ & $\mathrm{C} 2$ & 1 & PG \\
\hline & $\begin{array}{l}\text { Classifying changes in Community } \\
\text { institutions }\end{array}$ & $\mathrm{C} 2$ & 2 & PG \\
\hline & Explain one theory of social change & $\mathrm{C} 2$ & 3 & PG \\
\hline & $\begin{array}{l}\text { Identify the factors that cause social } \\
\text { change }\end{array}$ & $\mathrm{C} 2$ & 4 & PG \\
\hline & $\begin{array}{l}\text { Give examples of desired social } \\
\text { changeperubahan }\end{array}$ & $\mathrm{C} 2$ & 5 & PG \\
\hline & $\begin{array}{l}\text { Explaining the consequences of } \\
\text { modernization }\end{array}$ & $\mathrm{C} 2$ & 6 & PG \\
\hline & Applying the example of modernization & $\mathrm{C} 3$ & 7 & PG \\
\hline & $\begin{array}{l}\text { Implementing the era of globalization in } \\
\text { the lives of Indonesian people }\end{array}$ & $\mathrm{C} 3$ & 8 & PG \\
\hline & $\begin{array}{l}\text { Classifying the characteristics of modern } \\
\text { humans }\end{array}$ & $\mathrm{C} 2$ & 9 & PG \\
\hline & $\begin{array}{l}\text { Analyzing the phenomenon of } \\
\text { globalization }\end{array}$ & $\mathrm{C} 4$ & 10 & PG \\
\hline
\end{tabular}


Table 2. Sociology Teacher Interview Guidelines

\begin{tabular}{ll}
\hline No & \multicolumn{1}{c}{ Question } \\
\hline 1 & How long have you been teaching sociology for the Package C program at PKBM N \\
2 & $16 ?$ \\
3 & Do you have a pure sociology or sociology education background? \\
4 & Wow many package C students are currently studying at PKBM N 16? \\
5 & In the process of learning sociology, what methods or strategies do you usually use? \\
6 & Do you use media in the learning process? \\
7 & How do students respond to the media you use? \\
8 & Will students' interest in learning increase if you use media in the learning process? \\
9 & What are the difficulties experienced by students during the learning process? \\
10 & What factors caused the difficulty to occur? \\
11 & What factors caused the difficulty to occur? \\
12 & What learning resources do you use in teaching?
\end{tabular}

The main data obtained from the effectiveness test is the type of quantitative data. Quantitative data were obtained from the students' pretest and posttest learning outcomes. However, in testing the effectiveness of this electronic module product can also obtain qualitative data from the results of observations. Observations were made to see the results of observations of student activities. The data analysis technique carried out in the first stage is using a qualitative descriptive approach, namely describing the electronic module product after it is implemented in the form of a finished product and testing the level of product feasibility. The second stage uses a quantitative descriptive, which describes the effectiveness of the product to be implemented on competency standards, understands the concepts and ideas of social change material. Quantitative data obtained from students' pretest and posttest learning outcomes can be analyzed with the following steps; 1) Calculate the value of each student, calculate the effectiveness of improving student learning outcomes using the Normalized Gain (N-Gain) technique and Interpret the results of the N-Gain percentage using the criteria in table 3 (Arikunto, 1999).

Table 3. Categories of Interpretation of N-Gain Effectiveness

\begin{tabular}{cc}
\hline Percentage $(\%)$ & Criteria \\
\hline$<40$ & Ineffective \\
$40-45$ & Less effective \\
$56-75$ & Effective enough \\
$>76$ & Effective \\
\hline
\end{tabular}

\section{RESULT AND DISCUSSION}

The module used in this research is an electronic module for sociology subjects on social change material. The effectiveness of the module is seen from the impact that arises from an Action. In this study, the impact that arises on the use of electronic modules on student learning outcomes. The effectiveness test is used to see the level of success in learning activities. The electronic module can be said to be effective if the electronic module can have an impact on student learning outcomes where student learning outcomes increase between before and after using the electronic module. The electronic module that has been developed as a learning medium before being used by students has been tested for feasibility to material experts, media experts, and learning village experts with very feasible criteria. The data to see the effectiveness of the use of the electronic module is seen through the pretest and posttest scores and the completeness of learning outcomes. The minimum completeness criteria (KKM) for sociology class XII package C program is 70 .

Based on the results of data analysis obtained social change material sociology learning with the average value of students before using the electronic module is 48.15 and after using the electronic module is 78.42. If you look at the results of the pretest and posttest scores of students, it looks like there is a difference and there is an increase in the value of 30.27. Based on the $\mathrm{N}$-gain analysis, student learning outcomes show a value of 0.60 in the medium category and the effectiveness value of $\mathrm{N}$-gain in percent is 60 with a moderately effective category, which means that learning using electronic modules is able to improve student learning outcomes. The learning outcomes of these students are used to determine the effectiveness of the use of electronic modules in sociology subjects for social change. Assessment of learning outcomes for students aims to find out whether learning activities have been running effectively, the effectiveness of students can be seen in the 
ability of students to achieve the learning objectives that have been determined. The pretest was given with the aim of knowing the mastery of the initial concept before being given treatment with the electronic module, while the posttest was given with the aim of knowing the mastery of the concept after being given treatment in the form of learning using the electronic module. Judging from the KKM achievement score, which is 70, out of 38 students only 2 students achieved the KKM in the pretest, while in the posttest 32 students got a score that reached the KKM and 6 students scored below the KKM. If it is seen that there is a significant increase in the value of students who reach the KKM between the pretest and the posttest. So, the resulting electronic module is effectively used to improve sociology learning outcomes.

The results of the study show that the resulting electronic module is effectively used to improve sociology learning outcomes. This is inseparable from the first, the effectiveness of the module can improve student learning outcomes, this is caused by the module used for learning has a combination of pictures and videos which of course makes students not bored. E-modules assist in navigation, allow display or loading of images, audio, video, and are equipped with formative tests or quizzes (Fisnani et al., 2020; Gerhardt-Szép et al., 2017; Laili et al., 2019). Modules that include more interesting and varied productive material, will ask students to read and students can study independently at home with modules that have pictures, sounds, and videos that are not boring (Pertiwi, 2019; Rasmussen et al., 2020; Resita \& Ertikanto, 2018). Students who are not bored in taking lessons will find it easier to receive the information provided. Because of that the module used must be made as attractive as possible so that students are interested in following the learning process so that it has an impact on improving learning outcomes (Pradina \& Suyatna, 2018; Yulando et al., 2019).

Second, The effectiveness of the use of the module can be seen from the success of students in participating in learning. The existence of an electronic module makes it easier for students to obtain information about the material provided. This is caused by the electronic module whose content and language are easier to understand, there are pictures and videos and the appearance of the e-module is also interesting, so it can help students more easily understand the material. In general, learning by using e-modules is independent learning where the teacher acts as a facilitator while students build their own knowledge (Arifiyanti \& Ananda, 2018; Laili et al., 2019; Mutmainnah et al., 2021). The use of media in the learning process can make it easier for students to take part in learning, electronic modules also help students to be more focused, active, and think critically in participating in learning (Aufa et al., 2021; Fonda \& Sumargiyani, 2018; Sidiq \& Najuah, 2020). This is said to be effective because learning carried out with learning media can make learning less boring and fun so that students' interest and motivation to learn also increase.

Third, the effectiveness of using the module is shown by students being able to learn independently because all the material studied has been provided in the form of pictures, paragraphs and even videos that are packaged according to the characteristics of the students. Learning media that present creative and innovative learning materials will increase students' interest in learning (Irwansyah et al., 2017; Knoop-van Campen et al., 2020; Yuniarni et al., 2020). In addition, learning material delivered using media is more effective than learning without using media (Handayani et al., 2021; Imansari \& Sunaryantiningsih, 2017; Mentari \& Rosalina, 2018). This will motivate students to learn more independently and be less dependent on educators, this is certainly in accordance with the learning objectives of the package $C$ equality program.

Several factors cause the effectiveness of the use of electronic modules, namely the module has been validated by material experts, media experts, and learning village experts and is stated to be quite feasible and effective to be used in learning so that it can improve learning outcomes. This is in line with the results of research showing the results of data analysis, the results of the feasibility test of electronic module media on material experts I and II can be concluded that the Electronic Module is feasible and effective for use in the learning process (Elder et al., 2019; Susanti et al., 2020). Second, the electronic module is structured with contextual examples with language that is easier to understand so that students are motivated to learn (Fonda \& Sumargiyani, 2018; Triwahyuningtyas et al., 2020). Third, the modules are structured based on classroom learning consisting of learning outcomes and indicators, materials, concept understanding, summaries, practice questions, and self-reflection so that students can learn and measure their respective abilities. This is in accordance with research that developed web-based e-modules to improve the achievement of students' knowledge competence (Solihudin JH, 2018). Modules can improve the quality of learning processes and outcomes, so that students are more independent in the learning process (Laili et al., 2019; Utami et al., 2018). The electronic module allows students to optimize their way of learning independently, build concepts to be studied and develop reasoning power so that students can master the competencies that must be achieved in learning (Handayani et al., 2021; Seruni et al., 2020).

It can be understood that the resulting electronic modules are effectively used to improve sociology learning outcomes. The existing findings show that e-modules are able to improve students' critical thinking skills, obtaining positive responses from students and giving high percentages of improvement (Sidiq \& Najuah, 2020; Suastika \& Rahmawati, 2019). E modules can help students understand the material, so they can improve their learning outcomes (Dewi \& Lestari, 2020; Imansari \& Sunaryantiningsih, 2017; Subarkah et al., 2021). This e-module can be used by students to learn anytime and anywhere with the help of an electronic module. 
From the results of the research conducted, it can be seen that electronic modules are needed to help facilitate learning activities so that they can have a positive impact, especially in creating an effective, efficient, and interesting learning process in addition to being a supporting medium for the learning process, where electronic modules can provide variety for sociological learning so that students do not make the quiz more enjoyable, and the learning process can be more enjoyable. This study can be used as an evaluation in improving student learning outcomes further, so that improving the quality of education can be carried out optimally.

\section{CONCLUSION}

The developed electronic module is effectively used by students. The effectiveness of the use of the electronic module for sociology subjects, the material for social change is effectively used, where effectiveness can be seen based on the increased learning outcomes of students. effective, efficient, and interesting learning in addition to being a supporting medium for the learning process.

\section{REFERENCES}

Abror, M., Suryani, N., \& Ardianto, D. T. (2020). Digital Flipbook Empowerment as a Development Means for History Learning Media. JPI (Jurnal Pendidikan Indonesia), 8(2), 266. https://doi.org/10.23887/jpiundiksha.v8i2.24122.

Akita, S., \& Mori, K. (2021). How Implicit Image of Woman Changed in Japanese Sixth-Grade Children After a Gender Equality Education Lesson. The Journal of Social Studies Research, 9. https://doi.org/https://doi.org/10.1016/j.jssr.2021.05.004.

Andersen, T., \& Watkins, K. (2018). The Value of Peer Mentorship as an Educational Strategy in Nursing. Journal of Nursing Education, 57(4), 217-224. https://doi.org/10.398/01484834-20180322-05.

Andrinata, Sumarmi, \& I Komang Astina. (2016). Pengembangan Modul Geografi Pariwisata Berbasis Paket Wisata Pulau Lombok sebagai Upaya Memupuk Rasa Cinta Tanah Air pada Mahasiswa. Jurnal Pendidikan: Teori, Penelitian, dan Pengembangan, 1(10), 1999-2003. https://doi.org/10.17977/jp.v1i10.7339.

Angela, T. (2014). Challenges to Meaningful Learning in Social Studies - The Key Competences as an Opportunity to Students' Active Participation. Procedia - Social and Behavioral Sciences, 128, 192 197. https://doi.org/10.1016/j.sbspro.2014.03.142.

Aragonés-González, M., Rosser-Limiñana, A., \& Gil-González, D. (2020). Coeducation and Gender Equality in Education Systems: A Scoping Review. Children and Youth Services Review, 111. https://doi.org/10.1016/j.childyouth.2020.104837.

Arifiyanti, N., \& Ananda, K. (2018). Produksi Kosakata Anak melalui Electronic Wordless Picture Storybook. RETORIKA, 11(2). https://doi.org/10.26858/retorika.v11i2.6405.

Arikunto. (1999). Prosedur Penelitian Suatu Pendekatan Praktek. Rineka Cipta.

Asmi, A. R., Dhita Surbakti, A. N., \& C., H. (2018). E-Module Development Based Flip Book Maker for Character Building in Pancasila Coursework Sriwijaya University. Jurnal Pendidikan Ilmu Sosial, 27(1), 1-10. https://doi.org/10.17509/jpis.v27i1.9395.

Asrial, Syahrial, Maison, M., Kurniawan, D. A., \& Piyana, S. O. (2020). Ethnoconstructivism E-Module to Improve Perception, Interest, and Motivation of Students in Class V Elementary School. Jurnal Pendidikan Indonesia, 9(1), 30-41. https://doi.org/10.23887/jpi-undiksha.v9i1.19222.

Astalini, A., Darmaji, D., Kurniawan, W., Anwar, K., \& Kurniawan, D. A. (2019). Effectivenes of Using EModule and E-Assessment. International Journal of Interactive Mobile Technologies (IJIM), 13(09), 21-39. https://doi.org/10.3991/ijim.v13i09.11016.

Aufa, M. N., Rusmansyah, R., Hasbie, M., Jaidie, A., \& Yunita, A. (2021). The Effect of Using E-Module Model Problem Based Learning (PBL) Based on Wetland Environment on Critical Thinking Skills and Environmental Care Attitudes. Jurnal Penelitian Pendidikan IPA, 7(3), 401-407. https://doi.org/10.29303/jppipa.v7i3.732.

Bock, A., Modabber, A., Kniha, K., Lemos, M., Rafai, N., \& Hölzle, F. (2018). Blended Learning Modules for Lectures on Oral and Maxillofacial Surgery. British Journal of Oral and Maxillofacial Surgery, 56(10), 956-961. https://doi.org/10.1016/j.bjoms.2018.10.281

Budiaman, B., Komarudin, K., Nuruddin, N., \& Kustandi, C. (2021). Learning Design on Social Studies through Digital Book in Senior High School. International Journal of Interactive Mobile Technologies (IJIM), 15(09), 154. https://doi.org/10.3991/ijim.v15i09.18435.

Clay, V., König, P., Kühnberger, K.-U., \& Pipa, G. (2021). Learning Sparse and Meaningful Representations through Embodiment. Neural Networks, 134. https://doi.org/10.1016/j.neunet.2020.11.004.

Creswell, J. W. (2014). Research Design: Qualitative, Quantitative and Mixed Methods Approaches (4th ed.). 
Sage.

Daniel, K. N., \& Kamioka, E. (2017). Detection of Learner's Concentration in Distance Learning System with Multiple Biological Information. Journal of Computer and Communications, 05(04), 1-15. https://doi.org/10.4236/jcc.2017.54001.

Daniels, L. M., \& Gierl, M. J. (2017). The Impact Of Immediate Test Score Reporting on University Students' Achievement Emotions in the Context of Computer-Based Multiple-Choice Exams. Learning and Instruction, 5(2). https://doi.org/10.1016/j.learninstruc.2017.04.001

Dewi, M. S. A., \& Lestari, N. A. P. (2020). E-Modul Interaktif Berbasis Proyek terhadap Hasil Belajar Siswa. Jurnal Imiah Pendidikan dan Pembelajaran, 4(3), 433-441. https://doi.org/10.23887/jipp.v4i3.28035.

Diacopoulos, M. M., \& Crompton, H. (2020). A Systematic Review of Mobile Learning in Social Studies. Computers \& Education, 154. https://doi.org/10.1016/j.compedu.2020.103911.

Diah, \& Riyanto. (2016). Problem-Based Learning Model in Biology Education Courses to Develop Inquiry Teaching Competency of Preservice Teachers. Cakrawala Pendidikan, 35(1), 47-57. https://doi.org/10.21831/cp.v1i1.8364.

Divayana, D. G. H., Suyasa, P. W. A., \& Sugihartini, N. (2016). Pengembangan Media Pembelajaran Berbasis Web untuk Matakuliah Kurikulum dan Pengajaran di Jurusan Pendidikan Teknik Informatika Universitas Pendidikan Ganesha. Jurnal Nasional Pendidikan Teknik Informatika (JANAPATI), 5(3), 149. https://doi.org/10.23887/janapati.v5i3.9922.

Elder, J. J., Franco, K. A., Gulley, S. L., Hughes, C. T., \& Infanti, L. M. (2019). Implementation of Required Electronic Learning Modules to Enhance Nursing Pharmacotherapy Knowledge of Select Hematopoietic Stem Cell Transplant Topics. Biology of Blood and Marrow Transplantation, 25(3), S303. https://doi.org/10.1016/j.bbmt.2018.12.655.

Fadli, M. R., Sudrajat, A., Zulkarnain, A., Setiawan, R., \& Amboro, K. (2020). The Effectiveness of E-Module Learning History Inquiry Model to Grow Student Historical Thinking Skills Material Event Proclamation of Independence. Decision http://sersc.org/journals/index.php/IJAST/article/view/20146.

Faidah, N., Masykur, R., Andriani, S., \& Lina Herlina. (2019). Realistic Mathematics Education (RME) sebagai Sebuah Pendekatan pada Pengembangan Modul Matematika Berbasis Teori Multiple Intelligences. Realistic Mathematics Education (RME) as an Approach to Development of Mathematical Module Based on Multiple Intel. Indonesia Journal of Science and Mathematics Education, 02(3), 328-332. https://doi.org/10.24042/ijsme.v2i3.4396.

Fisnani, Y., Utanto, Y., \& Ahmadi, F. (2020). The Development of E-Module for Batik Local Content in Pekalongan Elementary School. Innovative Journal of Curriculum and Educational Technology, 9(1), 40-47. https://doi.org/10.15294/IJCET.V9I1.35592.

Fonda, A., \& Sumargiyani, S. (2018). The Developing Math Electronic Module with Scientific Approach Using Kvisoft Flipbook Maker Pro for XI Grade of Senior High School Students. Infinity Journal, 7(2), 109122. https://doi.org/10.22460/infinity.v7i2.p109-122.

Gerhardt-Szép, S., Dreher, S., Rüttermann, S., \& Weberschock, T. (2017). Konzeption und Implementierung eines neuartigen E-Learning-Moduls mit EbM-Lerninhalten im Fach Zahnerhaltungskunde. Zeitschrift Für Evidenz, Fortbildung Und Qualität Im Gesundheitswesen, 127-128, 72-78. https://doi.org/10.1016/j.zefq.2017.09.001.

Gunawan, G., Sahidu, H., Harjono, A., \& Suranti, N. M. Y. (2017). The Effect of Project Based Learning with Virtual Media Assistance on Student's Creativity in Physics. Jurnal Cakrawala Pendidikan, 2. https://doi.org/10.21831/cp.v36i2.13514.

Hamzah, I., \& Mentari, S. (2017). Development of Accounting E-Module to Support the Scientific Approach of Students Grade X Vocational High School. Journal of Accounting and Business Education, 1(1), 78. https://doi.org/10.26675/jabe.v1i1.9751.

Handayani, D., Elvinawati, E., Isnaeni, I., \& Alperi, M. (2021). Development of Guided Discovery Based Electronic Module for Chemical Lessons in Redox Reaction Materials. International Journal of Interactive Mobile Technologies (IJIM), 15(07), 94. https://doi.org/10.3991/ijim.v15i07.21559.

Hartini, S., Misbah, Dewantara, D., Oktovian, R. A., \& Aisyah, N. (2017). Developing Learning Media Using Online Prezi into Materials about Optical Equipments. Jurnal Pendidikan IPA Indonesia, 6(2), 313317. https://doi.org/10.15294/jpii.v6i2.10102.

Imansari, N., \& Sunaryantiningsih, I. (2017). Pengaruh Penggunaan E-Modul Interaktif terhadap Hasil Belajar Mahasiswa pada Materi Kesehatan dan Keselamatan Kerja. VOLT : Jurnal Ilmiah Pendidikan Teknik Elektro, 2(1), 11-16. https://doi.org/10.30870/volt.v2i1.1478.

Irwansyah, F. S., Lubab, I., Farida, I., \& Ramdhani, M. A. (2017). Designing Interactive Electronic Module in Chemistry Lessons. Journal of Physics: Conference Series, 895(1). https://doi.org/10.1088/17426596/895/1/012009.

Kaniati, R., \& Kusmayadi, D. (2013). Upaya Tutor dalam Menerapkan Pendekatan Pembelajaran Mandiri pada 
Warga Belajar Paket C di PKBM Pelita Pratama Bandung. Jurnal EMPOWERMENT, 2(2), 1-15. https://doi.org/10.22460/empowerment.v2i2p1-12.593.

Kisworo, B. (2017). Implementasi Media Pembelajaran Berbasis Prinsip-Prinsip Pendidikan Orang Dewasa PKBM Indonesia Pusaka Ngaliyan Kota Semarang. Journal of Nonformal Education, 3(1), 80-86. https://doi.org/10.15294/jne.v3i1.8987.

Knoop-van Campen, C. A. N., Segers, E., \& Verhoeven, L. (2020). Effects ff Audio Support on Multimedia Learning Processes and Outcomes in Students with Dyslexia. Computers and Education, 150(February), 103858. https://doi.org/10.1016/j.compedu.2020.103858.

Kostiainen, E., Ukskoski, T., Ruohotie-Lyhty, M., Kauppinen, M., Kainulainen, J., \& Mäkinen, T. (2018). Meaningful Learning in Teacher Education. Teaching and Teacher Education, 71, 66-77. https://doi.org/10.1016/j.tate.2017.12.009.

Laili, Ganefri, \& Usmeldi. (2019). Efektivitas Pengembangan E-Modul Project Based Learning pada Mata Pelajaran Instalasi Motor Listrik. Jurnal Ilmiah Pendidikan Dan Pembelajaran, 3(3). https://doi.org/10.23887/jipp.v3i3.21840. 306-309.

Logan, R. M., Johnson, C. E., \& Worsham, J. W. (2021). Development of an E-learning Module to Facilitate Student Learning and Outcomes. Teaching and Learning in Nursing, 16(2), 139-142. https://doi.org/10.1016/j.teln.2020.10.007.

Manurung, \& Panggabean. (2020). Improving Students' Thinking Ability in Physics Using Interactive Multimedia Based Problem Solving. Cakrawala Pendidikan, 39(2), 460-470. https://doi.org/10.21831/cp.v39i2.28205.

Mentari, T. A. S., \& Rosalina, L. (2018). Penggunaan Media Pembelajaran Multimedia Interaktif untuk Meningkatkan Aktivitas dan Hasil Belajar Mahasiswa pada Mata Kuliah Rias Wajah Karakter Foto/TV/Film Program Studi Pendidikan Tata Rias dan Kecantikan Jurusan Tata Rias dan Kecantikan FPP UNP. Journal of Education Scienties, 2(2), 194-199.

Mutmainnah, Aunurrahman, \& Warneri. (2021). Efektivitas Penggunaan E-Modul terhadap Hasil Belajar Kognitif pada Materi Sistem Pencernaan Manusia di Madrasah Tsanawiyah. Jurnal Basicedu, 5(2), 1625-1631. https://doi.org/10.31004/basicedu.v5i3.952.

Neppala, P., Sherer, M. V., Larson, G., Bryant, A. K., Panjwani, N., Murphy, J. D., \& Gillespie, E. F. (2018). An Interactive Contouring Module Improves Engagement and Interest in Radiation Oncology Among Preclinical Medical Students: Results of a Randomized Trial. Practical Radiation Oncology, 8(4), e190-e198. https://doi.org/10.1016/j.prro.2018.01.001

Nisa, A., Sudarmin, \& Samini. (2015). Efektivitas Penggunaan Modul Terintegrasi Etnosains dalam Pembelajaran Berbasis Masalah untuk Meningkatkan Literasi Sains Siswa. USEJ - Unnes Science Education Journal, 4(3), 1049-1056. https://doi.org/10.15294/usej.v4i3.8860.

Noroozi, O., \& Mulder, M. (2017). Design and Evaluation of a Digital Module with Guided Peer Feedback for Student Learning Biotechnology and Molecular LifeSciences, Attitudinal Change, and Satisfaction. Biochemistry and Molecular Biology Education, 45(1), 31-39. https://doi.org/10.1002/bmb.20981.

Pertiwi, P. (2019). Pengembangan Modul Elektronik Berbasis Problem Based Learning pada Kompetensi Merawat Sistem Rem Sepeda Motor untuk Meningkatkan Hasil Belajar Siswa. Jurnal Ilmiah Pendidikan Teknik dan Kejuruan, 11(2), 36. https://doi.org/10.20961/jiptek.v11i2.21878.

Pradina, L. P., \& Suyatna, A. (2018). Atom Core Interactive Electronic Book to Develop Self Efficacy and Critical Thinking Skills. Turkish Online Journal of Educational Technology-TOJET, 17(1), 17-23.

Prasasti, T. I., Solin, M., \& Hadi, W. (2019). The Effectiveness of Learning Media Folklore Text of North Sumatera Based on Blended Learning by 10th Grade Students of Vocational High SchoolHarapan Mekar-1 Medan. Bir-Le Journal, 4(2). https://doi.org/10.33258/birle.v2i4.548.

Raharjo, M. W. C., Suryati, S., \& Khery, Y. (2017). Pengembangan E-Modul Interaktif Menggunakan Adobe Flash pada Materi Ikatan Kimia untuk Mendorong Literasi Sains Siswa. Hydrogen: Jurnal Kependidikan Kimia, 5(1), 8. https://doi.org/10.33394/hjkk.v5i1.102.

Rasmussen, E., Goddard, A. G., \& Bayer, D. K. (2020). Use of Electronic Learning Modules Can Improve Medical Trainee Knowledge Regarding Anaphylaxis Diagnosis and Treatment. Annals of Allergy, Asthma \& Immunology, 124(3). https://doi.org/10.1016/j.anai.2019.12.018.

Resita, I., \& Ertikanto, C. (2018). Designing Electronic Module Based on Learning Content Development System in Fostering Students' Multi Representation Skills. Journal of Physics: Conference Series, 1022(1), 012025. https://doi.org/10.1088/1742-6596/1022/1/012025.

Seruni, R., Munawaroh, S., Kurniadewi, F., \& Nurjayadi, M. (2020). Implementation of E-Module Flip PDF Professional to Improve Students' Critical Thinking Skills through Problem Based Learning. Journal of Physics: Conference Series, 1521(4), 1-6. https://doi.org/10.1088/1742-6596/1521/4/042085.

Setiyani, Putri, D. P., Ferdianto, F., \& Fauji, S. H. (2020). Designing a Digital Teaching Module Based on Mathematical Communication in Relation and Function. Journal on Mathematics Education, 11(2), 223-236. https://doi.org/10.22342/jme.11.2.7320.223-236. 
Sidiq, R., \& Najuah. (2020). Pengembangan E-Modul Interaktif Berbasis Android pada Mata Kuliah Strategi Belajar Mengajar. Jurnal Pendidikan Sejarah, 9(1), 14. https://doi.org/https://doi.org/10.21009/JPS.091.01.

Simamora, F. G., Ertikanto, C., \& Wahyudi, I. (2017). Pengaruh Penggunaan Modul Pembelajaran Berbasis LCDS terhadap Hasil Belajar Siswa Fince. Jurnal Pembelajaran Fisika, 5(3), 91-101. http://jurnal.fkip.unila.ac.id/index.php/JPF/article/view/13023.

Sofyan, H., Anggereini, E., \& Saadiah, J. (2019). Development of E-Modules Based on Local Wisdom in Central Learning Model at Kindergartens in Jambi City. European Journal of Educational Research, 8(4), 1137-1143. https://doi.org/10.12973/eu-jer.8.4.1137.

Solihudin JH, T. (2018). Pengembangan E-Modul Berbasis Web untuk Meningkatkan Pencapaian Kompetensi Pengetahuan Fisika pada Materi Listrik Statis dan Dinamis SMA. WaPFi (Wahana Pendidikan Fisika), 3(2), 51. https://doi.org/10.17509/wapfi.v3i2.13731.

Suastika, I. ketut, \& Rahmawati, A. (2019). Pengembangan Modul Pembelajaran Matematika Dengan Pendekatan Kontekstual. JPMI (Jurnal Pendidikan Matematika Indonesia), 4(2), 58. https://doi.org/10.26737/jpmi.v4i2.1230.

Subarkah, C. Z., Alhak, A. A., Sari, S., Ruswandi, U., \& Rochman, C. (2021). Developing E-module on the Topic of Integrated Addictive Substances with Islamic Values. JTK (Jurnal Tadris Kimiya), 6(1), 1625. https://doi.org/10.15575/jtk.v6i1.9802.

Sunismi. (2015). Developing Guided Discovery Learning Materials Using Mathematics Mobile Learning Application as an Alternative Media for the Students Calculus II. Cakrawala Pendidikan, 34(5). https://doi.org/10.21831/cp.v3i3.7340.

Susanti, N., Yennita, Y., \& Azhar, A. (2020). Development of Contextual Based Electronic Global Warming Modules Using Flipbook Applications as Physics Learning Media in High Schools. Journal of Educational Sciences, 4(3), 541. https://doi.org/10.31258/jes.4.3.p.541-559.

Sutisna, A. (2016). Pengembangan Model Pembelajaran Blended Learning pada Pendidikan Kesetaraan Program Paket C dalam Meningkatkan Kemandirian Belajar. JTP - Jurnal Teknologi Pendidikan, 18(3), 156168. https://doi.org/10.21009/JTP1803.2.

Toma, R. B., \& Greca, I. M. (2018). The Effect of Integrative STEM Instruction on Elementary Students' Attitudes Toward Science. Eurasia Journal of Mathematics, Science and Technology Education, 14(4), 1383-1395. https://doi.org/10.29333/ejmste/83676.

Triwahyuningtyas, D., Ningtyas, A. S., \& Rahayu, S. (2020). The Problem-Based Learning E-Module of Planes Using Kvisoft Flipbook Maker for Elementary School Students. Jurnal Prima Edukasia, 8(2), 199-208. https://doi.org/10.21831/jpe.v8i2.34446.

Utami, Purnomo, \& Salam. (2018). Penanaman Sikap Sosial Melalui Pembelajaran IPS pada Siswa SMP Islam Sudirman Ambarawa Kabupaten Semarang. Sosiolum, 1(1), 40-52. https://doi.org/10.15294/sosiolium.v1i1.30446.

Wijayanti, N. P. A., Damayanthi, L. P. E., Sunarya, I. M. G., \& Putrama, I. M. (2016). Pengembangan E-Modul Berbasis Project Based Learning pada Mata Pelajaran Simulasi Digital untuk Siswa Kelas X Studi Kasus di SMK Negeri 2 Singaraja. Jurnal Pendidikan Teknologi Dan Kejuruan, 13(2), 184-197. https://doi.org/10.23887/jptk-undiksha.v13i2.8526.

Winatha, K. R., Naswan, S., \& Ketut, A. (2018). Pengembangan E-modul Interaktif Berbasis Proyek pada Mata Pelajaran Simulasi Digital Kelas X di SMK TI Bali Global Singaraja. Jurnal Teknologi Pembelajaran Indonesia, 8(1). https://doi.org/10.23887/jtpi.v8i1.2238.

Yulando, S., Sutopo, S., \& Franklin Chi, T. (2019). Electronic Module Design and Development: An Interactive Learning. American Journal of Educational Research, 7(10), 694-698. https://doi.org/10.12691/education-7-10-4.

Yuniarni, D., Sari, R. P., \& Atiq, A. (2020). Pengembangan Multimedia Interaktif Video Senam Animasi Berbasis Budaya Khas Kalimantan Barat. Jurnal Obsesi : Jurnal Pendidikan Anak Usia Dini, 4(1), 290. https://doi.org/10.31004/obsesi.v4i1.331. 